\title{
RELIGIOUS AND MULTICULTURAL EDUCATION: Introducing Interfaith Dialogue in the Indonesian Educational System
}

\author{
Nina Mariani Noor and Ferry Muhammadsyah Siregar \\ International Consortium of Religious Studies Yogyakarta
}

\begin{abstract}
Religious education which is taught in schools has a significant role in forming religious exclusivism and inclusivism, especially in Indonesia. It influences student's views on others. It also depends on the way those religion educations taught. There is also a need to have more efforts to bring the idea of interfaith dialogue into educational system including in higher educational level. There are some educational institutions which already involved in inter-faith dialogue in their curriculum such as the CRCS (Center for Religious and Cross Cultural Studies) and the ICRS (Indonesian Consortium for Religious Studies) at Gadjah Mada University. However, the number of primary educational institutions which involves interfaith dialogue is still limited. This work suggests that, for today's situation in Indonesian multicultural society, a need for reforming religion education curriculum in primary education is emerging. To make interfaith dialogue real in schools, the Ministry of Education in collaboration with Ministry of Religious Affairs is in a front line to arrange a new curriculum on religious education to be more pluralistic and affirm religious diversity in Indonesia including multi-religious education or inter religious education.
\end{abstract}

Key words: religious, multicultural, education, interfaith.

\section{INTRODUCTION}

Indonesia is a multicultural society which consists of many different ethnics, races, religions that spread out in thousands islands. The people have been living side by side for centuries and respecting each other regardless their ethnicity, religion, gender, and political preferences. Therefore, the Indonesian founding fathers, when the independence was declared, decided to establish a nation state based on Pancasila that affirms the diversity so that all Indonesians could be included in the nation state. Historically, religious tolerance has existed in this country for years although sometimes there were tension and conflict happen which cause violence in the name of religion that were committed by people who think that they are the only true. It shows that religions can trigger or make the conflicts even bigger and caused more victims.

Looking back at religious harmony in Indonesia, the government has decided 
three aspects of religious harmony, harmony among people of the same religion (internal religious harmony), harmony among people of different religions (external religious harmony) and harmony between religious people and the government. To make the harmony in real, education plays very significant role since education touch everyone in every level. Furthermore, for children and youth as the future generation, school education is the place where they get the education.

However, school education models in Indonesia have not contributed much on establishing tolerance among different adherents. Moreover, sometimes religious education brings about exclusivism and fanaticism among students (Yunus, 2007: 10). This religious intolerance threats Indonesia as the pluralistic society. Therefore, this paper attempts to examine religious education in Indonesia and discuss the possibility of implementing multicultural education as a way of introducing interfaith dialogue to students in schools. It would like to answer question such as how religion education in Indonesia do and how the future of implementing multicultural education in Indonesia based on the existing educational system do.

\section{EDUCATION IN INDONESIA}

Since our founding fathers have decided that Indonesia nation state is neither secular nor Islamic state but Pancasila state which support religious life, the education system is highly influenced by Pancasila. In general, there are two kinds of education institution available in Indonesia, secular and religious ones. Secular education institutions do not mean that those institutions do not teach religions at all rather they mainly focus on secular subjects in their curriculum but still teach religions as one of the subjects. In these institutions, students come from different religious backgrounds and they get religious education base on their own religion. While religious education institutions mainly focus on one religion teaching in their curriculum such as Madrasah, Islamic Universities for Islam, Seminari or Christian University for Christianity. Although they have their own specialties, both those institutions have to apply the National curriculum made by the government.

Talking about the contribution of those institutions in tolerance teaching, it can be said that secular institutions have bit more contribution than the religious ones since the nature of religious diversity among the students so that they have opportunities to interact with other religious adherents in their real life. However, actually in religious education institutions, there are still chances for us to maximize their contribution to elevate tolerance. It would be explored further in the last part of this paper. 


\section{THE MODEL OF RELIGIOUS EDUCATION}

As I have mentioned before that all education institutions in Indonesia teach religion in their curriculum made by the Government through Ministry of Education and Ministry of Religious Affairs. In the New Order era, it seemed that relationship among different religion adherents was at the best situation in which there was very few conflict that happen because of religious issue. Pancasila was successfully playing its unifying rules and the government made a top-down policy to control the harmony. However, those top down policies have lost their significance after the fall of New Order. The diversity that exists in Indonesia cannot be homogenized anymore. Each culture asks for its own role and influence.

During New Order era, education in Indonesia only paid limited attention on how we appreciate and respect religious and cultural diversity. Homogenization process and internalization of cultural hegemony was taught through civic education like Pancasila and Citizenship, training of P4 (guidance for internalization and externalization of Pancasila) and even through religious education (Baidhawy, 2007). According to Suratno (2006), religious education in Indonesia partly contributes on intolerance among religious adherents because of some mistakes made.

First, the process of religious education tends to be the process of indoctrination in which religion is looked as a dogmatic thing and critical thinking is absent. Second, it mostly emphasizes on normative aspects only not other related aspects such as socio-historical and moral aspects and another aspects related to the concrete social life that is plural, include the plurality of religion.

Third, generally, teachers of religious education exclusively only know their own religious teaching and do not have enough knowledge about other religious teachings. Therefore, it only concerns on one side perspective. Fourth, religious education only emphasizes on cognitive aspects in which its evaluation only base on students' ability to memorize the materials. The last one, the government's policy also leads to the failure of religious education.

Baidhawy in his observation found out that religious education in both public and religious schools tends to be exclusive in which they only teach "their own systems of religion or belief as the truth and the only path to salvation and regarding other religions as inferior". As a result, when the state or the schools teach about official religions, it means that education has failed to advance the values of democratic pluralism (Baidhawy, 2007: 19). Discussing religious education, Hermans (2003) divides three approaches to religious education in a religiously pluralistic context. They are mono-religious education, multi- 
religious education and inter-religious education (Hermans, 2003: 337-349).

Mono-religious education only focuses on one religion and it is well known as transmission model. The aim of this religious education is appropriation of particular religion. In this model, when students are taught about other religions, it is not about concerning on those religions rather on the insight of that particular religion to others. In social uniformity context, it aims to internalize of religion as an important system of values and norms. Absolute truth claim is always invisible in this model (Sterkens, 2001: 49-51)

Hermans further argues that there are two kinds of mono-religious education. The first version does not allow sufficiently for change either within religions or within religious people. Religion is seen as self-contained phenomena and there is no need to contextualize the rituals, stories, symbols and customs of the religion. The second version of religious education based on an open concept of tradition and certain forms of contextual theology. In this version allows students to experience religion, not only to memorize it. Both those two version of mono-religious model do not allow religious diversity (Hermans, 2003: 339). Unfortunately, based on explanation above, religious education in Indonesia can be included in this model.

Multi-religious education focuses on the diversity of religions in society. Unlike in mono-religious model, in this model religions are seen from their own auto perspectives not from other religions' views. The theology of this model is pluralism on the equality of different religions. Therefore, salvation is not only can be gained from one single religion, but through other religions also. The aim of this model is to introduce students to plurality of religions so that affectively it will instill an interest in religions and cultivate a respectful attitude towards people from other religions (Hermans, 2003: 341-342).

Inter-religious education covers both mono-religious and multi religious education and recognizes the religious pluralism in society at large and in schools in particular but also on dialogue between them (Hermans, 2003: 337-349). To make dialogue happen, there is a need of knowledge about other religions. There are two kinds of dialogic models based on the religion and its aims. If the dialogue is based on a particular religion and aims at developing a particular religious identity such as a Muslim identity, it is a simple dialogic model. The second one is a parallel dialogic model in which it is based on different religion and aims at developing different religious identities (Hermans, 2003: 344).

This inter religious model of religious education deals extensively with changes and innovation in religion. The inter-religious education deals positively with 
religious pluralism. It also offers the opportunity to develop the religious self more fully. In addition, interreligious education only leads to students to understand a particular religion "from the inside" (auto perspective). Therefore, it can be said that only inter religious education which gives students insight into a religion other than their own and which uses encounter with the other for the development of the religious self.

After reviewing models on religious education, religious education in Indonesia which still mono-religious model have to be transformed into interreligious education model, or at least multi-religious education. There is a high possibility of implementing inter-religious education model in public schools since the students are coming from diverse religious background. To start with, the government could establish a curriculum in inter-religious education and it is not a big deal since there are a lot of academies and religious leaders who concern on inter religious dialogue. While, although there is also possibility of implementing inter-religious education in religious schools but since its lack of diversity on religious background, multi-religious education is most proper to practice in these schools. However, it also important to invite students in these schools to have a real dialogue with other religions adherents.

\section{MULTICULTURAL EDUCATION AND ITS SIGNIFICANCE FOR INTERFAITH DIALOGUE}

Besides we can change our religious education into inter-religious education, there is still one model that can be implemented in Indonesia education system. Therefore, this part explores multicultural education that might be applicable in Indonesia. In the sociopolitical context, Nieto says that multicultural education:

"Is a process of comprehensive school reform basic education for all students? It challenges and rejects racism and other forms of discrimination in schools and society and accepts and affirms pluralism (ethnic, racial, linguistic, religious, economic, and gender, among others) that students, their communities, and teachers reflect. Multicultural education permeates the schools' curriculum and instructional strategies, as well as the interactions among teachers, students, and families, and the very way that's schools conceptualize the nature of teaching and learning. Because it uses critical pedagogy as its underlying philosophy and focuses on knowledge, reflection, and action, (praxis) as the basis for social change, multicultural education promotes democratic principles of social justice" (Nieto, 2000: 305)

From the definition, there are seven characteristics of multicultural education, 
which are multicultural education as antiracist education, basic education, important for all students, pervasive, education for social justice, a process and critical pedagogy.

Defining antiracism, antiracism is opposition of racism. Racism is defined as the denial of the moral equality of all human beings and refers to an institutional or social structure of racial domination and also to individual actions, belief, and attitudes consciously or not which express and justify the superiority of one racial to another, so antiracism means a value consists of striving to be without racist attitudes oneself and also being prepared to work against racist attitudes in others and racial injustice in general. Antiracist education includes three components.

First is non racist moral consciousness. It is the belief that all persons have equal worth regardless race in intellectual matters and also in attitudes and emotions. Students have to be taught understanding racism, particularly as psychological and historical phenomenon. The second is understanding racism. There are three components. One is the psychological dynamic of racism such as scapegoating, stereotyping.

Second is the historical dynamics of racism in its particular forms such as slavery, Nazism, and colonialism. Third is the role of individuals in accepting or denying racist institutions, patterns, and system. In studying historical dynamics of racism should involve teaching the victimization of some groups by others.

The third component is opposition to racism. In terms of opposition to racism, students need to avoid racism in actions and attitudes and also to develop a sense of responsibility concerning manifestations of racism in other persons and society (Blum, 1998).

In multicultural education, antiracist is the core of the education. And for being antiracist and anti-discriminatory schools have to pay attention to all areas such as the curriculum, choice of materials, sorting policies, and teacher's interactions and relationships with students and their families (Nieto, 2000: 306). In Indonesia, racism may be not so popular since we are all Asian, but ethnicity is a crucial issue. Since Indonesia consists of many different ethnics and there is a growing number of conflicts which are caused by ethnicity, I think, antiracism is still relevant to be taught in school but we can contextualize it into anti-ethnocentrism. We have to emphasize that all ethnics in Indonesia has the same rights to live and develop in Indonesia. No single ethnicity is superior that others.

Multicultural literacy as a basic education means that it is indispensable for 
living in today's world like reading, writing and arithmetic literacy. Most curricula do not consider excluded groups' contribution on the history and also other subjects like the arts, literature, geography, science, and philosophy on their own terms. Unless their students develop multicultural literacy, schools have not already done their complete or proper job. Through multicultural education, students are expected to develop social and intellectual skills that would help them understand and empathize with a wide diversity of people (Nieto, 2000: 310-311). In Indonesia, since Javanese is the majority, it seems that they contribute more than other ethnics that can be seen from historical text book taught in school. There is a need of correcting or comprehending our history to take all ethnicities contribution into accounts.

Multicultural education is important for all students since education that is available now mostly only give a partial and biased education that make some parties are invisible like females and other minority groups. Multicultural education means an inclusive education which covers all people and for all peoples regardless their ethnicity, language, religion, gender, race, class, sexual orientation or other difference. Moreover, students from majority groups need more multicultural education because it is often that they are the most uneducated about diversity. In Indonesian context, for example, Javanese are the dominant group and many Javanese students may still think that their group as the norm and see others as deviation since they only get limited information about other groups through schools. Consequently, children from dominated groups may develop feeling inferiority whereas children from Javanese mostly develop superior feelings.

Furthermore, multicultural education encourages students and teachers to put their learning about diversity into action for social justice. In multicultural perspective practiced in the classroom should not only allow discussion that focus on social justice but also welcome them. The discussions can be on topics such as poverty, discriminations, war, the national budget that might affect differently among different communities and what students can do to change them.

By encouraging students to learn about diversity and then promoting action for social justice, in my opinion, it will be very valuable in Indonesian context. The discussions which may happen will make students realize that besides religious issues, actually, there are many more important things that have to be dealt with. For example, social justice is much more important than going to “jihad' to defend religion by doing suicide bombing which make other people suffer.

Since education is a process, multicultural education is a process also. 
Multicultural education is ongoing and dynamic and it involves primarily relationships among people. This process should be supported by other policies and practices like teacher education programs to increase teachers' knowledge, skills, and roles in multicultural education, and enhance families' roles to make the insights and values of the community more persistent in school. This process, therefore, is complex, problematic, time consuming and controversial.

Finally, in multicultural education, students are encouraged to view events and situations from varied point of views using critical thinking, reflection and action. In other words, multicultural education is a critical pedagogy which empowers students based on their own experiences and perspectives (Nieto, 2000: 305-318).

\section{CONCLUDING REMARKS}

Education has been proved effective in building and influencing the way of thinking, behavior and attitude of children and youth. Especially religious education which is taught in schools has a significant role in forming religious exclusivism or inclusivism, depends on the way those religion education taught. Religious people have already succeeded in introducing interfaith dialogue among different religion adherents to reduce the number of conflicts flamed by religious issues. However, since those attempts are mostly effective at the elite level not in the grass root level, it need more effort to bring the idea of interfaith dialogue into educational system.

There are some educational institutions which already involved interfaith dialogue in their curriculum like the CRCS (Center for Religious and Cross Cultural Studies) and the ICRS (Indonesian Consortium for Religious Studies) at Gadjah Mada University. However, the number of primary educational institutions which involves interfaith dialogue is still limited. Therefore, for today's situation in Indonesia multicultural society, a need for reforming religion education curriculum in primary education is emerging. To make interfaith dialogue in real in schools, the Ministry of Education in collaboration with Ministry of Religious Affairs can arrange the new curriculum on religious education to be more pluralistic and affirm religious diversity in Indonesia like multi-religious education or inter religious education.

Besides that, it is not only religious education curriculum that can be reformed, but also broader educational system by implementing multicultural education. Supported aspects of multicultural education are already there since the nature of Indonesia as a multicultural society. What to be need is only willingness 
and hard effort to make it real. Hopefully, in the future, when Indonesia is able to implement a multicultural education there will be no more conflicts that cause many losses and threat the unity of Indonesian nation-state. Since a multicultural education affirm the diversity among students and treat them equally in education so nobody claims superiority among others.

\section{BIBLIOGRAPHY}

Baidhawy, Zakiyuddin. 2007. " Building Harmony and peace through multiculturalist theology-based religious education: an alternative for contemporary Indonesia." in British Journal of Religious Education. Vol 29, No, 1, January 2007, pp. 15-30

Blum, Lawrence. (1998). "Antiracism, Multiculturalism, and Interracial Community: Three Educational Values for a Multicultural Society", in Larry May et.all (ed), Applied Ethics A Multicultural Approach, New Jersey, Prentice Hall.

Hermans, Chris A.M.2003. Participatory Learning; Religious Education in Globalizing Society. Leiden, Boston: Brill

Nieto, Sonia. 2000. Affirming Diversity: The Sociopolitical Context of Multicultural Education. New York: Longman

Sterkens, Carl. 2001. Interreligious learning; the problem of interreligious dialogue in primary education. Leiden, Boston, Koln: Brill

Suratno, 2006. "Intolerance and the failure of religious education" retrieved from http://suratno77.multiply.com/calendar/item/10005. retrieved May 14, 2010

Yunus, Abd Rahim. 2007. "Pendidikan Toleransi Dalam Konteks Indonesia." paper presented in International workshop on teaching for tolerance in the indonesian Context (The Contribution of School Education) organized by Alauddin State Islamic University (UIN) Makassar in collaboration with The Oslo Coalition on Freedom of Religious Belief 
